\title{
Feature
}

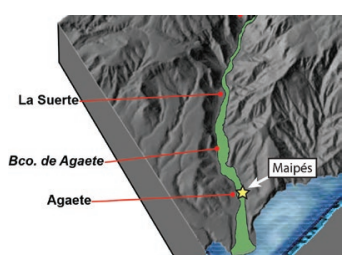

\section{Sacred ground; the Maipés necropolis of north-west Gran Canaria}

Gran Canaria, like most of the Canary Islands, shows evidence for young basaltic volcanism in the form of cinder cones and valley-hugging lava flows. These landforms were of no particular use to the aboriginal population, nor to the subsequent Spanish settlers, and young lava flows and lava fields are still referred to as 'malpais' (badlands) in the Canary Islands. In north-west Gran Canaria, one such lava flow fills the bottom of a steep-sided valley, which reaches the sea at the present day village of Agaete. The lava flow erupted c. $3030 \pm 90 \mathrm{yr}$ BP and displays a total length of $\sim 11 \mathrm{~km}$. At its distal end, just outside Agaete, it hosts one of Europe's largest and most important pre-historic burial sites constructed of volcanic rock: the Maipés necropolis. Over 700 pre-historic tombs (or tumuli) constructed from the aa-type clinker materials have been identified on top of the valley-filling lava flow. The up to soccer-ball sized vesicular clinker fragments are sufficiently low in density to provide abundant, workable basalt blocks for the construction of the tumuli, allowing the pre-hispanic aboriginal population to create a large and magnificent 'sacred ground' in an otherwise barren landscape.

The Canary archipelago lies in the eastern central Atlantic Ocean, some $150-500 \mathrm{~km}$ off the coast of north-west Africa, between $29^{\circ} 25^{\prime} \mathrm{N}$ and $27^{\circ} 37^{\prime} \mathrm{N}$ and $18^{\circ} 10^{\prime} \mathrm{W}$ and $13^{\circ} 20^{\prime} \mathrm{W}$. The seven Canary Islands are of different ages and relate to a mantle plume, as summarized in 2015 by Troll and colleagues in this journal (see Further reading) (Fig. 1). Typically, three main classes of volcanic rocks are observed in the Canaries: (1) mafic lavas and scoria ranging from subalkaline basalts to silica undersaturated nephelinites; (2) felsic rocks that range from trachytes to varieties of rhyolites and phonolites; and (3) plutonic rocks that include layered gabbro to alkali gabbro and syenite intrusives. Following Schmincke and Sumita's work in 2010, the most widespread rock type identified is mafic alkaline lavas and scoria, while highly evolved magma makes up a comparatively small volume on most of the Canary Islands. The exceptions are Gran Canaria and Tenerife, where an appreciable volume of felsic igneous rocks are exposed. Intermediate magma types are typically rare to absent.
About 80 percent of the volume of Gran Canaria island was formed during the Miocene shield building period (see Fig. 1), that occurred between 15 and 9 million years ago, and which was dominantly basaltic. This so-called 'Shield Stage' concluded on Gran Canaria with the emission of voluminous trachytes, phonolites and evolved peralkaline rhyolites (comendites), which in part erupted as highly explosive ignimbrites. The shield stage was followed by an erosional hiatus of $\geq 4$ million years. A later cycle of alkaline volcanic eruptions, known as the 'Roque Nublo cycle', commenced at $\sim 4.5 \mathrm{Ma}$ and lasted until $\sim 3$ Ma. Most of the inland's peaks today are composed of rocks of this period, as noted by Perez-Torrado and co-workers in 1995. This Pliocene period produced lavas and some small volume pyroclastic flows and it is likely that a large stratovolcano was also created at this time (the Roque Nublo volcano) but which subsequently decayed to produce the extensive breccias that still fill many of the valleys on Gran Canaria. Some spectacular intrusions like the Risco Blanco phonolite also formed at that point.
Valentin $\mathbf{R}$.

Troll ${ }^{1,2}$, Alejandro

Rodriguez-

Gonzalez² Frances

M. Deegan', Francisco José

Perez-Torrado ${ }^{2}$, Juan Carlos

Carracedo ${ }^{2}$, Konstantinos Thomaidis', Harri Geiger ${ }^{1}$ \& Fiona C. Meade $^{1}$

'Department of Earth Sciences, Section for Mineralogy, Petrology and Tectonics (MPT), Uppsala University, Uppsala, Sweden ${ }^{2}$ Instituto de Estudios Ambientales y Recursos Naturales (i-UNAT), Universidad de Las Palmas de Gran Canaria (ULPGC), Las Palmas de Gran

Canaria, Spain

frances.deegan@geo.uu.se 


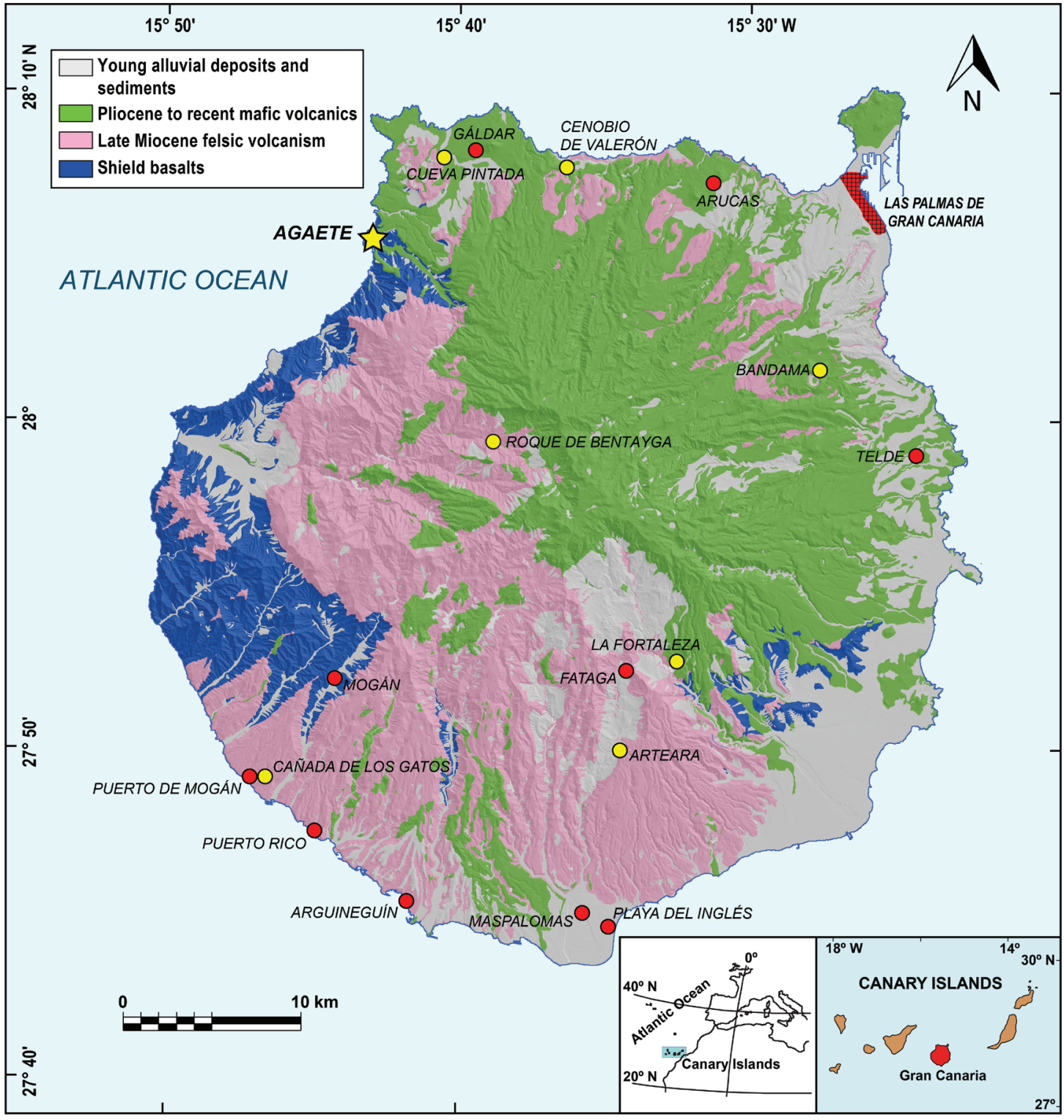

The most recent cycle of volcanic activity on the island (the 'Post-Roque Nublo cycle') is thought to have started some $2.5 \mathrm{Ma}$, with a peak production in the Late Quaternary, and is considered to be still active. A series of young vents in the North and Northeast of the island form broad alignments and gave rise to the 'Las Palmas volcanic field', a large pock-marked area around the capital city of Gran Canaria. The products of this most recent activity are highly mafic and strongly alkaline in composition and comprise dominantly basanites, nephelinites and foidites (see e.g. Rodríguez-Gonzalez and coworkers in 2009, and Aulinas and colleagues in 2010). Notably, this latest eruptive cycle on Gran Canaria was witnessed by aboriginal islanders and indeed, one of the youngest eruptions on the island, the Bandama eruption (c. $1970 \pm 70 \mathrm{yr} \mathrm{BP}$ ), is known to have buried an aboriginal millstone.

\section{Pre-Hispanic Gran Canaria}

At the time of the Spanish conquest, the Canary Islands were inhabited by a variety of indigenous communities. The pre-colonial population of the Canaries is generically referred to as 'the Guanches', although, originally, the term Guanches referred to the inhabitants of Tenerife only. It appears that interaction between the islands was relatively limited in pre-Hispanic times, which led to somewhat distinct population characteristics and socio-cultural developments on the different islands.

In respect of the arrival of the aboriginal settlers, the assumed dates range from the first to the fifth centuries $\mathrm{BC}$ and the most popular hypothesis is that they were 'planted' by sea-faring Mediterranean peoples, including animals and seeds, to colonize the islands. Libyan-Berber script was found in several
Fig. 1. Simplified geological map of Gran Canaria (modified after Carracedo \& Troll, 2016). A basaltic shield (blue) is overlain by felsic Miocene volcanism (pink), which in turn is capped by Pliocene younger rocks in the north and east of the island (green). Agaete is located on the NW coast of the island and is marked by a yellow star. Several important present-day settlements are marked with red circles. Archeological sites shown in Fig. 2 are marked with yellow circles. 
pre-Hispanic settlements on Gran Canaria, supporting a broadly North African origin of the aboriginal (pre-Hispanic) population. We have records that the aboriginal name for Gran Canaria Island was Tamarán, meaning 'Land of the Brave'. The early Spanish records and the archaeological evidence suggests that the pre-Hispanic people of Gran Canaria herded goats, sheep and pigs, and that they grew wheat, barley, peas and lentils. Herds were frequently moved in search of pasture and the animals were kept for milk, meat and cheese, but also to make clothing and bone tools. The fibres from reeds and palm trees were widely used to make mats and fishing nets, as well as shoulder bags and baskets. Moreover, seeds of the palm tree were very popular due to their sugary sap. Roots of ferns were widely used to make flour, often mixed with lentil or grain to prepare 'Gofio', a stew that is still popular on the Canary Islands today. Agriculture reached a relatively high state of development on Gran Canaria. This was in part due to the advantages of the local geography, which allowed irrigation systems to be developed in many barrancos of the island (Fig. 2).

This situation enabled Gran Canaria to sustain a larger pre-Hispanic population than elsewhere in the archipelago. Fishing and the collecting of shellfish was also very popular and is recorded by the reasonably frequent 'concheros'. These are concentrations or piles of shells near the shore were groups of aboriginal people gathered their catch and pooled the shellfish before carrying it inland. According to the early Spanish records, a widespread aboriginal fishing technique was to exploit tidal pools where fish and shellfish frequently ended up trapped at low tide. The hunting of wild animals was also common, including various birds such as pigeons, crows and shearwaters, but also the giant Canary rat (now extinct), as well as several species of large lizards (most also extinct by now).

The most common type of housing for the aboriginal people were natural caves, formed by erosion, but volcanic tubes and tunnels were also used, and artificial caves were excavated from soft pyroclastic rocks (see Fig. 2). This type of settlement developed locally into pueblo-style villages, for example at Acusa, Agüimes, Arguineguín, Arucas, Fataga, Gáldar, Telde, Tirajana and at Tirma. Stone house existed too (see Fig. 2) usually with wooden ceilings and earth or stone slabs as the roof. In addition, smaller huts or shelters were widespread throughout the island and were probably associated with seasonal land use, similar to 'shielings' perhaps.

At the time of the Spanish conquest, the preHispanic society on Gran Canaria was in transit from a tribal to a class society and a 'nobility' group had emerged, and this class executed economic and political control. The highest political position was
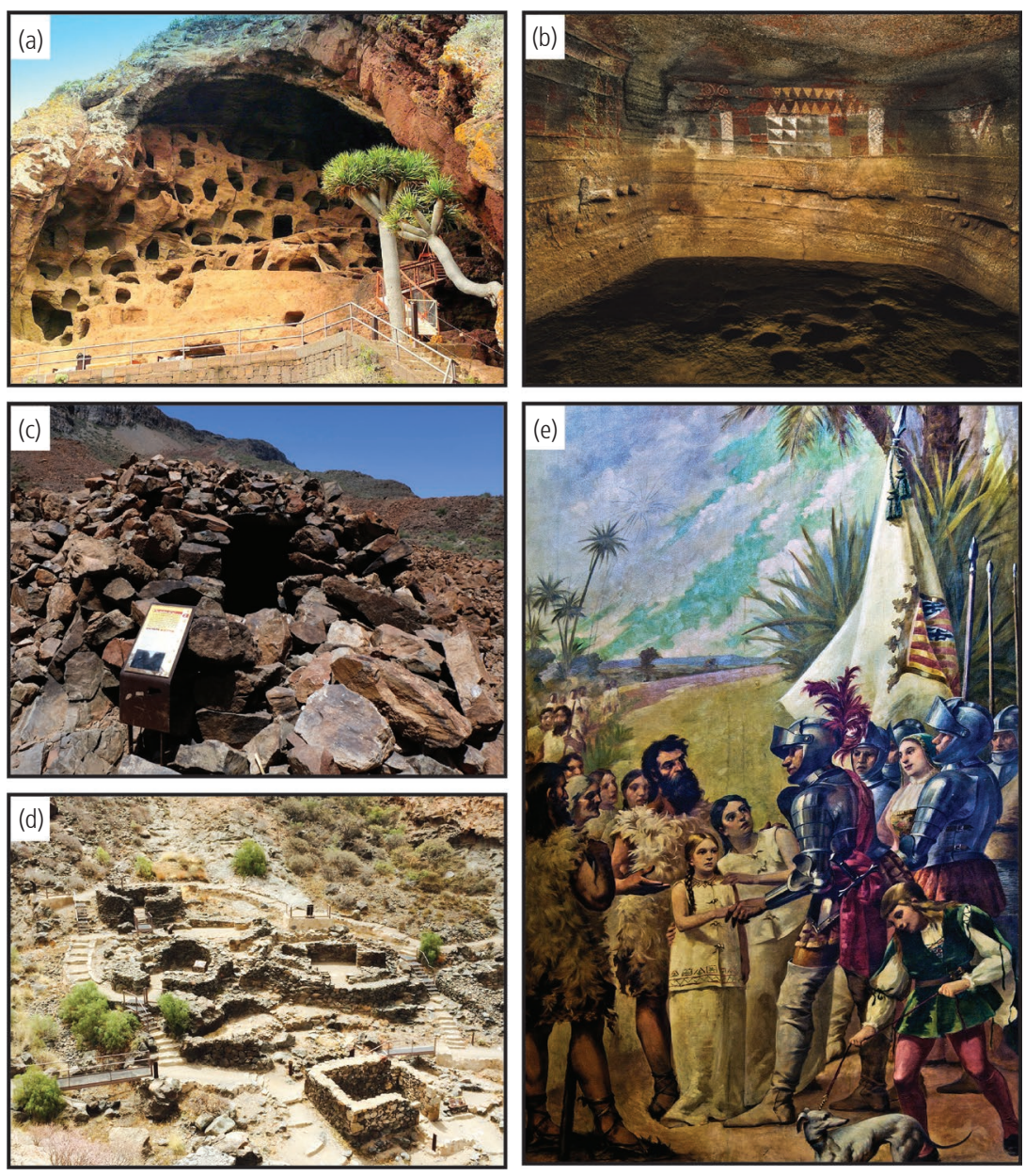

Fig. 2. Pre-hispanic sites on Gran Canaria. a. Cenobio de Valerón, an aboriginal grain store in NW Gran Canaria. Within the archipelago this type of collective barn is only found on Gran Canaria, indicating a complex society and political arrangement on the island (image courtesy of Claudio Moreno). b. Cueva Pintada in Gáldar, a ceremonial site excavated within lapilli and ash beds (image courtesy of Claudio Moreno). c. Arteara, South Gran Canaria, a necropolis within a large block field at the foot of the steep, eroding cliff of Barranco Fataga. d. Cañada de los Gatos village is located near the coast in Barranco de Mogán and forms part of a larger, likely town-sized aboriginal settlement. e. The painting 'El Adelantado y los Guanches' was created in 1906 by Manuel Gonzalez Mendez (1843-1909) and is a romantic view of the first encounter between the Spanish Conquistators and the native Guanche population. The original painting is on display in the main hall of the Canary Parliament in Santa Cruz de Tenerife.

that of the Guanarteme (chief redistributor), as he was called on Gran Canaria. He shared out land amongst the noble families and presided at social events. He was also responsible for finding solutions to conflicts over pasture land and water access and to ensure the sustainability of their agricultural efforts. Over time, this system gave the redistributor a king-like status and seven territorial demarcations (counties) emerged on the island arranged in a 'cake-slice', each with independent water access from the central highlands.

Many of the mid-fourteenth to eighteenth century texts and the various archaeological remains found on the islands suggest that veneration of the sun, the moon and the stars was widespread. Religious 


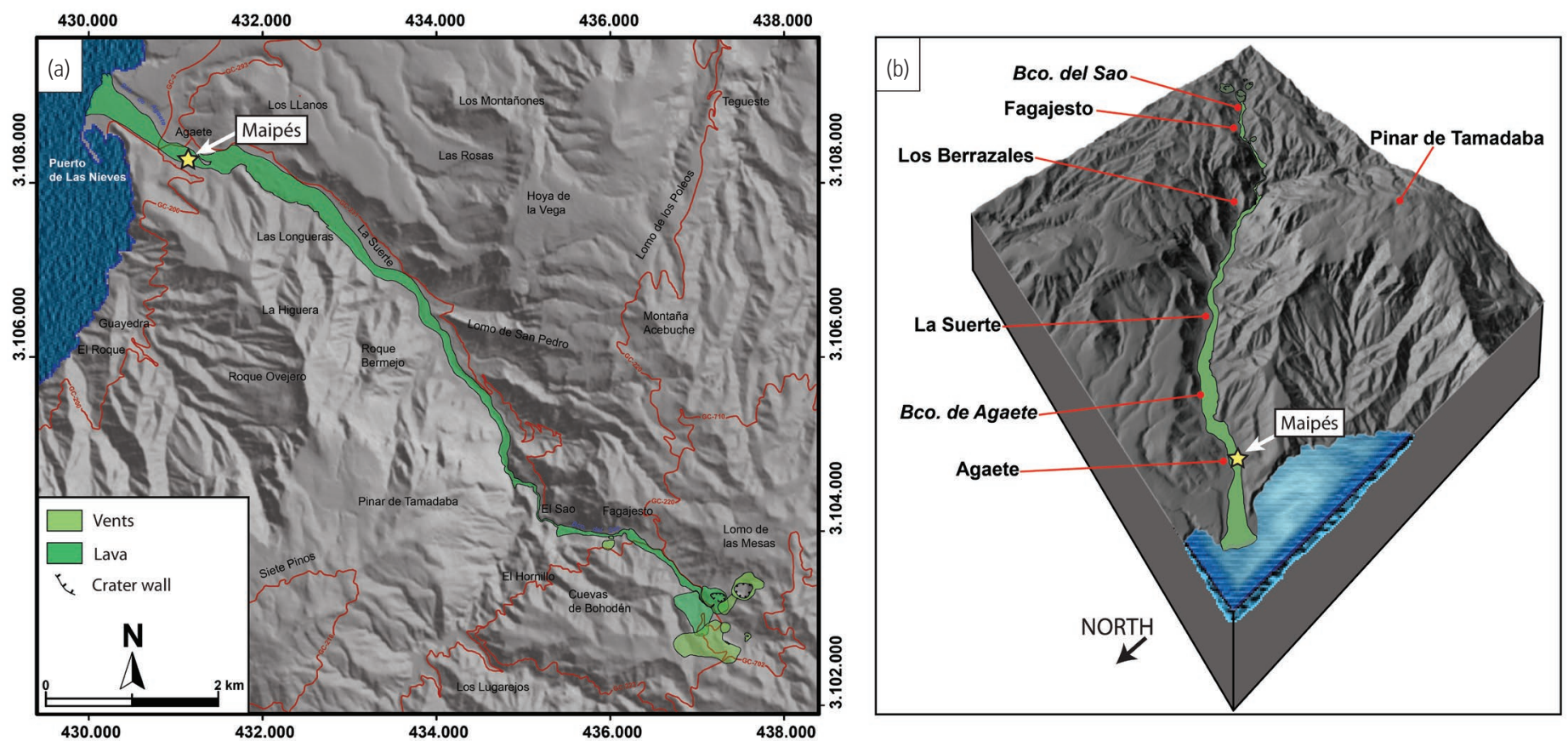

practices were closely related to the natural cycles, providing an annual rhythm to community life. The aboriginal population believed in an afterlife, which is underscored by the practice of mummification and the careful placement of the deceased that were often surrounded by gifts. Food offerings were frequently placed beside the corpses and there are usually some personal items like a weapon, an obsidian tool, or some ornamental objects such as necklaces or a figurine. Mummification of the body was almost certainly restricted to members of the 'noble' class and for this the corpse was washed with salt water and then exposed to the sun, but more complex methods were also employed, involving, for example, vegetable oils and lard. The corpse was then wrapped and sewn into funeral bags with the number of layers reflecting the social status of the deceased. Aboriginal burial grounds were frequently located near significant landscape features, and burial places were considered 'sacred ground' by the aboriginal people. Early Spanish sources from the time of the conquest report that the aboriginal pre-Hispanic population considered burial places as portals or gates for their ancestors and deities, and offerings were frequently made in such sites. Offerings were burnt on charcoal and the 'faycan' (the shaman) read God's will from the charred animals and the smoke they produced. We know little about the details of their deities, but from sources at the time just after the Spanish conquest we know of special ceremonies for good harvests, for rites of passage, and of elaborate burial rites for some members of the upper class. Burial rites in particular had much to do with the concept of death as another way of life and it appears that the spirits of their ancestors had large importance for the living. The ancestors were thought to visit regularly and to travel across the seas, usually in the form of fog, clouds or rain, thus making low-lying coastal areas with frequent sea fog, as in the north-west of Gran Canaria, particularly attractive for such religious sites.

\section{Dramatic changes}

When the Castilian conquerors arrived on Gran Canaria in the 1470 s, small posts were set up, which were at first not especially alarming to the aboriginal population. Indeed, the conquest of Gran Canaria was a relatively slow process and stretched from 1478 to 1487. It involved a series of battles between the Guanches and the 'Conquistadors' and although the Guanches were blessed with some initial military successes, they were eventually overwhelmed. This brought a traumatic change to their way of life.

Once the conquest was completed, a sudden introduction into the cultural, economic, political system of the growing Spanish empire caused a rapid decline of Guanche society as an independent entity (see Fig. 2e). Assimilation of aboriginal population and culture by the arriving Spanish is still seen today in many pre-hispanic place names on the island, like Arguineguín, Agaete and Telde, while on the other hand, the Spanish conquerors drove a zerotolerance policy towards the old faith of the aboriginal population. A new branch of the Catholic church was employed to oversee the transition of the pre-Hispanic population to Christianity. This branch would later
Fig. 3. Map and reconstructed topographic projection showing the valley filling nature of the Agaete lava flow. a. The lava erupted from a set of vents some $\sim 11 \mathrm{~km}$ inland and progressed all the way to the coast. $\mathbf{b}$. Oblique 3D block diagram of the Agaete valley from the Northwest. Maipés is located at the widening of the barranco Agaete just when it opens up towards the sea. This topography caused a widening of the lava flow and produced a delta-type lava platform near the coast. 

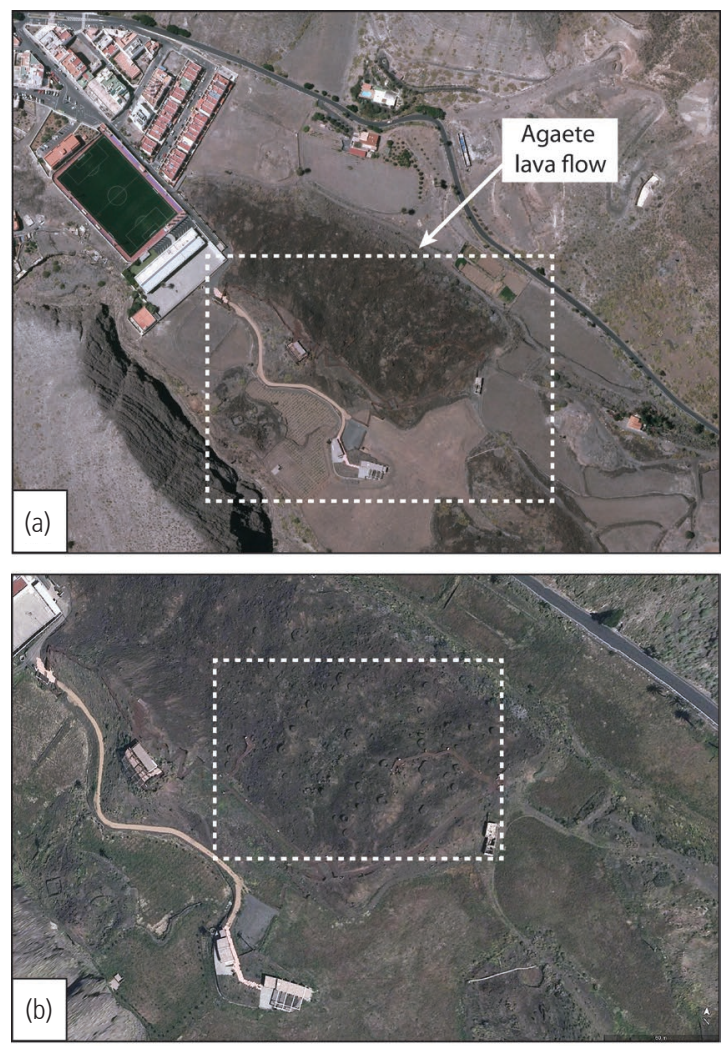

Fig. 4. a. Aerial view of the Maipés necropolis located at the outskirts of present-day Agaete village (image from GRAFCAN, Ortoexpress 2012; Empresa Cartográfica de Gran Canaria, SA Gobierno de Canarias, España). b, c. A zoom onto the necropolis (white box in a and b), shows the high area density of tumuli that characterizes the site, totaling over 700 in number.

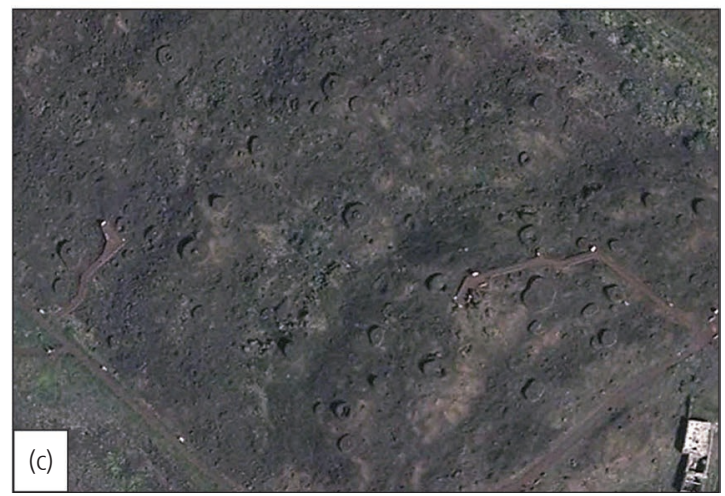

become an oppressive tool all over South America and many parts of mainland Europe itself: the 'Spanish inquisition'.

Genetic studies are instructive in considering the population, and in 2003 a research article by MacaMeyer and coworkers in the European Journal of Human Genetics compared aboriginal (Guanche) mitochondrial DNA collected from Canarian archaeological sites to that of today's Canarian population. The results show that despite the continuous changes in the population (Spanish colonization, slave trade, mixing with Latin American groups), direct aboriginal maternal lineages constitute between 42 and 73 percent of the present-day Canarian gene pool. In other words between about 40 and 75 percent of today's Canary population has partly aboriginal ancestry. In another study in 2009, Fregel and coworkers estimated, based on Y-chromosome and mitochondrial DNA haplogroup frequencies, that the relative female and male aboriginal contributions to the present-day Canary Island population is c. 42 percent and 16 percent, respectively. This estimate suggests that the female pre-Hispanic aboriginals are more strongly represented in today's population than male aboriginal influences, consistent with the radical transition brought about by the Spanish conquest. In addition, Fregel and co-workers found Berber Y-chromosome lineages in the indigenous remains, confirming a north-west African origin for the ancestors of the pre-hispanic population. Furthermore, a mild influence from the Middle East is also indicated by Y-chromosomes as another Canary ancestral group.

\section{The Maipés necropolis and the current archaeological park at Agaete}

The south and west of Gran Canaria is marked by a relatively dry climate and the landscape is dominated by brown, reddish and yellow-to-greenish colours. In contrast, recent lavas in the north and north-east of the island usually display characteristically deep black to dark red colours, and are often marked by an intense shine due to their glassy surfaces. Young lavas like these at Maipés (Figs 3, 4) cannot be easily exploited as a resource and are to this day known as 'malpaís' (badlands) in the Canary Islands.

The Maipés site is located within a wide barranco (named 'Barranco de Agaete') and right at the bottom of the high cliffs of 'Pinar de Tamadaba' (see Fig. 3), providing a rocky back-drop to the stunning archaeological setting (see Fig. 4). The principal lava flow that underlies Maipés emerges from a vent complex near Fagajesto, some $11 \mathrm{~km}$ further inland, as described in detail by Rodriguez-Gonzalez and collaborators in 2009. This particular lava flow is the longest of the Holocene lavas on the island and is the only one that reached the sea, where it formed a small lava platform. The lava emerged from the crater as a pahoehoe flow, and columnar jointing is locally present in the upper portion of the flow. Terraces are common here. Degassing mounds (hornitos) are sometimes observed on the surface of the lava and on occasion, intercalated remains of now oxidized and red sediment are seen and lava tubes are found higher up the barranco. In lower barranco Agaete, the lava developed into blocky lava. The lava must have advanced like a bulldozer down the main Agaete valley, developing distinct block-lava characteristics, including pronounced top and bottom breccias. Fluvial erosion in the ravine incised the lava in several places. Exposed sections though the lava reveal plant moulds at the bottom, contacts with the previous relief, and local lahar deposits that apparently 

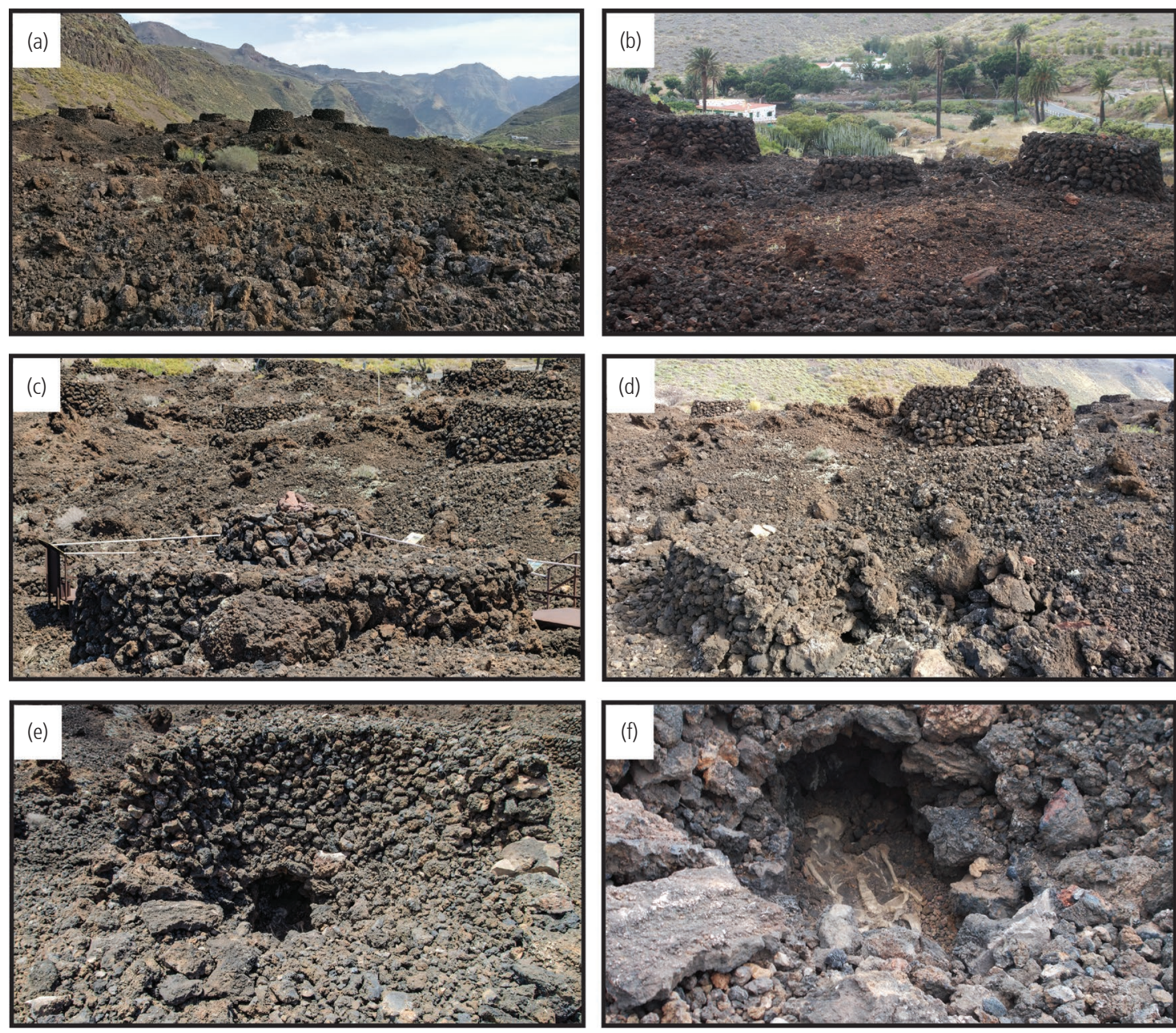

preceded the lava flow. Furthermore, occasional larger blocks of older material seemingly fell from the slopes into the lava, implying that the eruption might have been accompanied by earthquakes too. Near the village of Agaete, the lava flow expands laterally into the mouth of the flat-bottomed barranco, which has a U-shaped morphology here, thus promoting the formation of several lava tongues.

The necropolis of Maipés is located just outside the port village of Agaete and is built on the main lobe of the lava flow. It represents a major pre-Spanish burial site and the Archaeological Park of Maipés is, next in importance to the one in Arteara (see Fig. 2c), the largest and most important one on Gran Canaria. The ancient cemetery displays over 700 tombs (tumuli) and by being constructed on the 3-kyr-old Agaete lava flow (see Fig. 4), it constitutes 'one of the largest and most important pre-historic burial sites within volcanic material in Europe', and indeed the world. The site was declared an 'Archaeological Zone of Special Cultural Interest' in 1974 for its obvious archaeological value, but we here also point to the impressive geology represented by the lava flow on which it is placed.

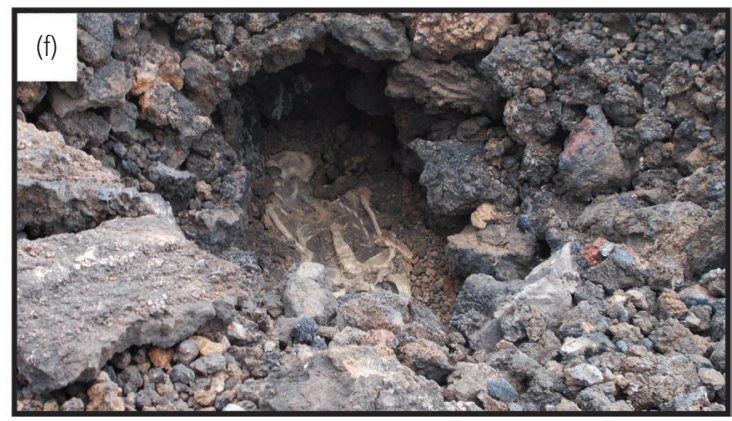

The present 'Archaeological Park' that has been built around the remains provides over $1000 \mathrm{~m}^{2}$ of accessible surface area (see Fig. 4), and gives almost hands-on access to the tombs, and offers an interpretation centre and a small museum. Indeed, detailed inspection of the Maipés necropolis can be accomplished on a pathway walk, which is over one kilometre long and is adapted for visitors with reduced mobility. The raised walkway takes visitors past the most prominent tombs and offers detailed explanations on well laid out noticeboards that explain the types of tombs and the world of the ancient island dwellers (Figs 5, 6).

The tombs usually have a tapered shape and can reach eight metres in diameter and up to three metres in height. Inside, a stone casing was set to the dimensions of the deceased and was covered with lava blocks. Most of the tombs were finished off at the top with various coloured stones, usually red or yellow. The funerary floor was often laid out with plants or herbs (dragon tree, pine, cedar, juniper or thyme), and covered with goat and sheepskins. Most of bodies were found lying in an upright (supine) position. The oldest burials here date back to over
Fig. 5. a-f. Over 700 identified tumuli at Maipés comprise dominantly circular structures, but are of variable size. They usually house an inner chamber where the deceased was laid to rest. The skeleton in (f) is a replica. The largest one is labelled the 'kings tumulus', but actually contained a young female skeleton. 
1300 years ago (seventh to eight century $\mathrm{AD}$ ) and the youngest to $\sim 600$ years BP, i.e. right up to the Spanish conquest. The biggest tomb of all is known as the 'king's tomb' although it hosted the remains of a young woman or girl. The remains of eight bodies found outside the main burial area are suspected to represent social outsiders, perhaps even foreigners who landed on the island's shores before the Spanish conquest.

The notable geological feature in the Maipés archaeological park is the spectacular ' $a$ ' or blocky lava flow and the abundant inclusions in the basaltic lava rock. Inclusions within the lava comprise reddish pick-up clasts from the valley walls and floor, as well as frothy light-coloured sediments, that are of preisland origin (xeno-pumice) similar to those described by authors in 2003 and 2012 (Fig. 7). These xenopumice inclusions look like magmatic pumice on first glance but actually comprise minerals typical of continental derivation, such as quartz with rutile inclusions, as well as thin heavy mineral bands.

This 'exotic' mineral assemblage points to a derivation of the minerals in these former sedimentary fragments from neighbouring Africa, because such a 'continental' mineralogy is uncharacteristic for Gran Canaria. The islands' magmatic products are usually quartz undersaturated and do not contain primary magmatic quartz crystals. The xeno-pumice fragments instead represent frothed-up sediments of the c. $2 \mathrm{~km}$ thick pre-island sedimentary layers that are resting on the Jurassic igneous ocean crust beneath the volcanic edifice of Gran Canaria. The frothy xenopumice fragments thus represent messengers from a long-gone era before the island started to build up by lava extrusion on the ocean floor. They provide a rare glimpse into the deep rock structure beneath the island of Gran Canaria and the type of geology prevalent before the upheaval caused the formation of the present-day volcanic island.

In a more local context, however, Maipés in north-west Gran Canaria, and Arteara in south Gran Canaria, became centres of burial as well as places of worship because large quantities of loose rock of workable size were a readily available natural resource at these sites. At Maipés, these loose rocks originate from the top and bottom breccia of a recent aa-type lava flow providing abundant and up to soccer-ball sized vesicular scoria fragments that are sufficiently low in density to be used as workable blocks for the construction of the tumuli. Thus the origin of Maipés is rooted in the combination of a geological resource with an awe-inspiring geographical site, which together allowed the pre-Hispanic aboriginal population to create a unique place of memory and worship on the island and thus one of the most important historical burial sites in volcanic materials in the world: the sacred grounds of Maipés.
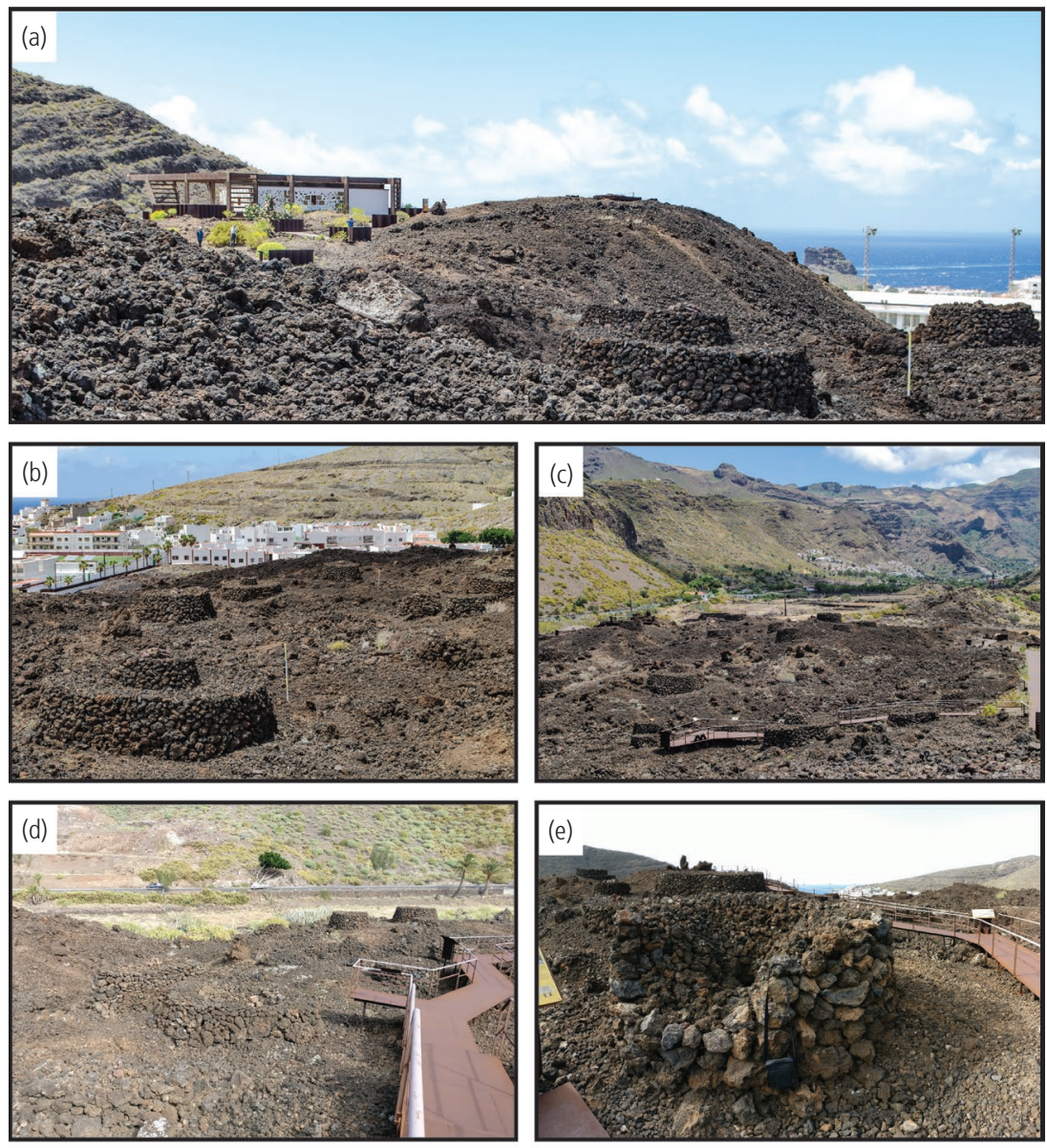

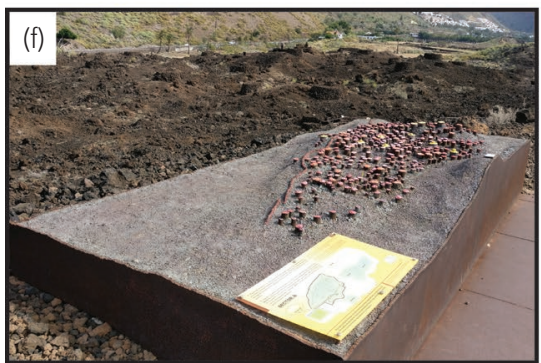

\section{Acknowledgements}

We are indebted to the Cabildo de Gran Canaria for access to and preservation of the Maipés site. We are grateful to Christine Karsten and Sofie Troll for help during fieldwork. The Swedish Research Council (VR), the Swedish Foundation for International Cooperation in Research and Higher Education (STINT), the University of Las Palmas de Gran Canaria, and the Royal Swedish Academy (KVA) for generous financial and logistical support of our work.

\section{Suggestions for further reading}

Aulinas, M., Gimeno, D., Fernandez-Turiel, J.L., Font, L., Perez-Torrado, F.J., Rodriguez-Gonzales, A. \& Nowell, G.M. 2010. Small-scale mantle
Fig. 6. a-g. The Maipés archaeological park offers a visitor centre and a large number of explanatory boards along a $\sim 1 \mathrm{~km}$ paved walkway, allowing the visitor to fully emerge into a long gone world, without risking destruction of the site. 

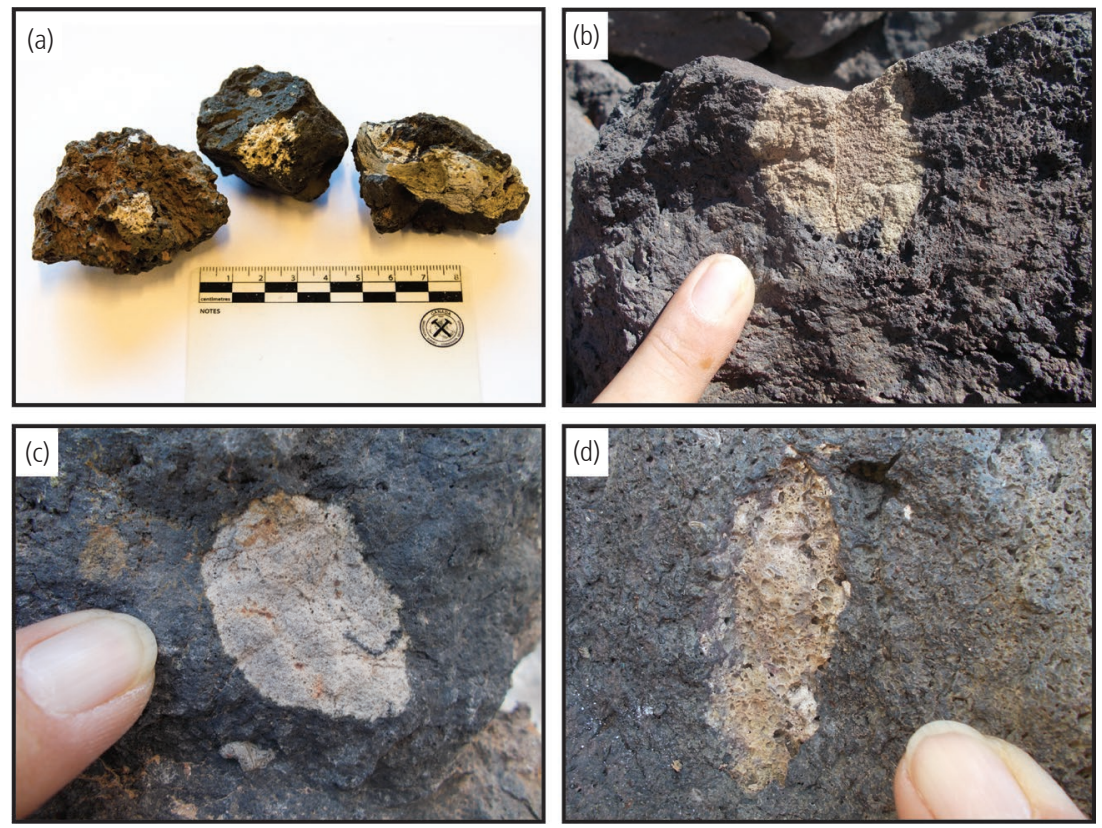

Fig. 7. Xenopumice inclusions occur in the lavas here at Maipés and are messengers from times before the island existed. Many are frothed up and some contain quartz with rutile inclusions and other 'exotic' continental minerals that are not native to the island. These come from the Mesozoic to Miocene sedimentary strata that rests on the igneous ocean crust and which originated from the African continent some $250 \mathrm{~km}$ to the east. heterogeneity on the source of the Gran Canaria (Canary islands) Pliocenequaternary magmas. Lithos, v.119, pp.377-392.

Benítez Padilla, S. 1963. Una Breve Excursión Científica por Gran Canaria (itinerario Geo-arqueológico de la Isla a Lo Largo de sus dos Principales Carreteras). El Museo Canario, Las Palmas de Gran Canaria.

Carracedo J.C. \& Troll V.R. 2016. The Geology of the Canary Islands. Elsevier, Amsterdam, pp.1-625.

Carracedo, J.C., Day, S., Guillou, H., RodriguezBadiola, E., Canas, J.A. \& Perez-Torrado, F.J. 1998. Hotspot volcanism close to a passive continental margin: the Canary Islands. Geological Magazine, v.135, pp.591-604.

Fregel, R., Gomes, V., Gusmão, L., González, A.M., Cabrera, V.M., Amorim, A. \& Larruga, J.M. 2009. Demographic history of Canary Islands male genepool: replacement of native lineages by European. BMC Evolutionary Biology, v.9, p.181

Glas, G. 1764. The History of the Discovery and Conquest of the Canary Islands with an Inquiry into the Origin of the Ancient Inhabitants to which is Added a Description of the Canary Islands, Including the Modern History of the Inhabitants, and an Account of their Manners, Customs, and Trade. Dodsley \& Durham Printing Co., London.

Hoernle, K.A. \& Schmincke, H.-U. 1993. The role of partial melting in the 15 Ma geochemical evolution of Gran Canaria. A blob model for the Canary Hotspot. Journal of Petrology, v.34, pp. 599-626.

Krastel, S. \& Schmincke, H.-U. 2002. Crustal structure of northern Gran Canaria deduced from active seismic tomography. Journal of Volcanology and Geothermal Research, v.115, pp.153-177.

Maca-Meyer, N., Arnay, M., Rando, J.C., Flores, C., González, A.M., Cabrera, V.M. \& Larruga, J.M. 2003. Ancient mtDNA analysis and the origin of the Guanches. European Journal of Human Genetics, v.12, pp.155-162.

de Paz Sanchez, M. \& Quintero Sanchez, O. 2009. History of the Canary Islands. Gobierno de Canarias, Las Palmas de Gran Canaria.

Perez-Torrado, F., Carracedo, J. \& Mangas, J. (1995). Geochronology and stratigraphy of the Roque Nublo Cycle, Gran Canaria, Canary Islands. Journal of the Geological Society, v.152, pp.807-818.

Rodriguez-Gonzalez, A., Fernandez-Turiel, J.L., PerezTorrado, F.J., Hansen, A., Aulinas, M., Carracedo, J.C., Gimeno, D., Guillou, H., Paris, R. \& Paterne, M. 2009. The Holocene volcanic history of Gran Canaria island: implications for volcanic hazards. Journal of Quaternary Science, v.24, pp.697-709.

Schmincke, H.-U. \& Sumita, M. 2010. Geological Evolution of the Canary Islands: a Young Volcanic Archipelago of the Old African Continent. Görres Druckerei und Verlag GmbH, Koblen.

Troll V.R., Klügel A., Longpré M.-A., Burchardt S., Deegan F.M., Carracedo J.C., Wiesmaier S., Kueppers U., Dahren B., Blythe L.S., Hansteen T., Freda C., Budd D.A., Jolis E.M., Jonsson E., Meade F., Harris C., Berg S., Mancini L., Polacci, M. \& Pedroza, K. 2012. Floating stones off El Hierro, Canary Islands: xenoliths of pre-island sedimentary origin in the early products of the October 2011 eruption. Solid Earth, v.3, pp.97-110.

Troll, V.R., Deegan, F.M., Burchardt, S., Zaczek, K., Carracedo, J.C., Meade, F.C., Soler, V. Cachao, M., Ferreira, J. \& Barker, A.K. 2015. Nannofossils: the smoking gun for the Canarian hotspot. Geology Today, v.31, pp.137-145.

Wölfel D.J. 1940. Die kanarischen Inseln und ihre Ureinwohner [Translation of handwritten Italian manuscript by Leonardo Torriani, 1590]. Koehler Verlag, Leipzig. 